\title{
Lessons from the History and Challenges for the Future of the Swiss Debt Brake: A Note
}

\author{
Peter Siegenthaler
}

JEL-Classification: H6

Keywords: debt, debt brake, fiscal rules, Switzerland

The genesis of the Swiss debt brake goes back to the nineties, which were in no respect a success story for the Swiss economy. In Switzerland this decade was strongly influenced by a heavy real estate crisis (with a loss in the books of the financial sector of more than 10 percent of GDP). A slack in economic growth and a huge increase in public debt were the consequences of this crisis. Public debt in percent of GDP nearly doubled in 10 years. In the federal budget, adjustment programs followed each other on a year by year basis. Inspired by positive experiences with fiscal rules on the cantonal level the "Schuldenbremse" was developed. Although the introduction of the fiscal rule was preceded by an adjustment program, the cyclical adjusted federal budget showed an important deficit at the starting point. For the first 3 years of the implementation of the debt brake the rule had to be loosened. For each year decreasing limits for the structural deficit were fixed. Decisive for the effectiveness of the debt brake was certainly the overwhelming consent in the popular vote in 2001 with a majority of 85 percent.

Three lessons can be learned from the history of the Swiss debt brake :

First, take profit of an adverse development in public finances. It is the right moment to find the necessary political support for a fiscal rule, which will in any case limit the discretionary scope of politics. Perhaps it is the noblest task of politics to construct intelligent rules.

Second, you cannot expect to start in the new rule-based world with a balanced budget. The ideal starting point will never come. Start and loosen the rule for the first years of its implementation. But you have to fix clear limits for the allowed deficits.

And third, look for the highest possible democratic legitimation. The Swiss direct democracy is in this respect a clear advantage.

Let me conclude with the most important challenges for the Swiss debt brake in the future. 
At first it is clearly the demographic development, the aging of the population, with its increasing pressure on the pension and health systems. The debt brake for the federal budget is not apt to handle this problem. It would result in a crowding out of other important, less legally bound and protected public activities, such as education and infrastructure. There is a clear need for structural reforms in the pension and health systems. To fight against the danger of possible political blockades, we have to develop specific fiscal rules for the different social insurances, as we already know it for our unemployment insurance.

Beside that we have to find an effective solution for the "too big to fail problem". As a hostage of systemic banks public finances are confronted with risks, which cannot be handled by a fiscal rule. By preference this risk should be eliminated by a stronger funding of the banks' balance sheets and an internationally coordinated resolution regime. If necessary even a direct intervention in the business model of systemic banks must be taken in consideration. 